\title{
COMMODIFICATION OF ISLAMIC VALUES IN THE ADS OF "HIJAB FRESH" BODY LOTION
}

\author{
Asla Eva Setya \\ Udayana University, Indonesia \\ aslasetya13@gmail.com \\ Ni Made Ras Amanda Gelgel \\ Udayana University, Indonesia \\ rasamanda13@unud.ac.id \\ Ade Devia Pradipta \\ Udayana University, Indonesia \\ deviapradipta88@unud.ac.id
}

\begin{abstract}
The development of the advertising world often follows the development of society. The close relationship between human and their religion is one of the factors that influence the packaging and advertising of products and then is wrapped in religious values. Changes and additions to the value of products with values that increase the selling power of the product are called commodification expressed by Mosco. One product advertisement with the commodification of religious values is a fresh hijab body lotion advertisement. This paper will describe how the process of commodification in advertisements through the symbols in the ad. This study is a qualitative study using Peirce's semiotic analysis. The process of commodification occurs through the shifting of the message and the impression given is seen from the clothing used by actors in advertisements, the behavior of actors in accordance with Islamic teachings and messages with words that reinforce advertisements in the form of audio or written on packaging and advertisements in mass media. So through this advertisement it is learned that religious values are often commodified to increase the sale value of a product through the symbols in its advertisements.
\end{abstract}

Keyword: Fresh Hijab; Advertisement; Commodification; Religious Values 


\begin{abstract}
Abstrak
Perkembangan dunia iklan kerap mengikuti perkembangan masyarakat. Kedekatan hubungan manusia dengan agamanya menjadi salah satu faktor yang mempengaruhi kemasan dan iklan produk untuk kemudian berbalut nilainilai Agama. Perubahan dan penambahan nilai produk dengan nilai-nilai yang meningkatkan daya jual produk dinamakan komodifikasi yang diutarakan oleh Mosco. Salah satu iklan produk dengan komodifikasi nilai-nilai agama ini adalah iklan body lotion hijab fresh. Tulisan ini akan menggambarkan bagaimana proses komodifikasi dalam iklan melalui simbol-simbol dalam iklan tersebut. Penelitian ini adalah penelitian kualitatif dengan menggunakan analisis semiotika Peirce. Proses komodifikasi terjadi melalui pergeseran pesan dan kesan yang diberikan terlihat dari busana yang digunakan oleh aktor dalam iklan, perilaku aktor yang sesuai dengan ajaran Islam serta pesan dengan katakata yang mempertegas iklan baik berupa audio ataupun tertulis pada kemasan dan iklan di media massa. Maka melalui iklan ini dipelajari bahwa nilai-nilai agama kerap kali terkomodifikasi untuk meningkatkan nilai jual sebuah produk melalui simbol-simbol dalam iklannya.
\end{abstract}

Kata Kkunci: Hijab Fresh; Iklan; Komodifikasi; Nilai-nilai Agama.

Accepted : April 21, 2020 Reviewed: May 6, 2020 Published: June 1, 2020

\title{
Introduction
}

Religion has a function as a social control for human life. But at this time, religion is experiencing a shift in function. The function value of religion becomes a commodity and religion itself undergoes the process of commodification. This religion has the main function as individual control (Habermas, 2015). Religion has control over human norms and ethics. The implication is that religion makes humans produce a delusion, a belief in a creature or spirit. The spirit is considered a "solutive being" that can solve all the problems that exist in human life and cause segregation. Religion is also a rite for humans (Kamim, 2017).

Now religion is deliberately traded by using symbols on goods that are traded and introduced, such as bath soap, fabric softeners, body lotion, shampoo, etc. this was conveyed in the news about halal products by the bbc.com news website on August 14, 2019 "Halal products: From refrigerators to cosmetics, certification as a business trend or religious capitalization?". Community dependence on the label "halal" from the Indonesian Ulema Council (MUI), especially for Muslim communities, 
encourages goods and companies to compete in installing labels for profit. By using religious values to seek profit by using opportunities referred to as "Islamic consumption", producers use Islam as a tool (Fealy \& White, 2008).

Karl Marx had predicted religion would influence the values of buying and selling. Marx's criticism of religion in "Critique on Hegel's Philosophy of Right" reveals that religion as opium cannot be considered as completely wrong. It is precisely this criticism of Marx that can help religious people be able to religion critically and without the need to pawn their common sense (Murtadho, 2016).

Da'wah is a tool of the commodification of religion in attracting consumers. One of the media is using Advertisements (Fakhruroji, 2014). advertising has become a product of television that connects the creators of advertising with consumers. Advertising on television emphasizes the important elements in communication to consumers, this is to make it easier for consumers to catch the message to be conveyed by the advertisers (Piliang, 2012).

The Ads has become a product of television that connects the creators of advertising with consumers. Advertising on television emphasizes the important elements in communication to consumers, this is to make it easier for consumers to catch the message to be conveyed by the advertisers.

The commodification of religious values is widely used in advertising. Examples of such advertisements are Wardah product advertisements: Halal from the start, shampoo product advertisements and clothing products, one of which is Nike. Islam is the majority religion in Indonesia. Based on data from BPS (Central Statistics Agency) in 2010 around $87.18 \%$ of people in Indonesia are Muslim. The trend of halalbased products continues to grow and more and more from time to time. Trade competition has also become very fierce with many ad producers making advertisements using Islamic religious propaganda that contains religious values and teachings. And from the State of Global Islamic Economy Report in 2017-2019, Indonesia is ranked 11th.

This form of commodification is indeed unconsciously consumed every day by the public. The attractive nature of advertising makes it able to encourage consumers to buy products or services. This success was 
marked by an increasing percentage of advertising purchases in the media. Nielsen shed 2019 quarterly advertising expenditure data to grow around $8 \%$ from the previous year 2018. The commodification is the process of changing the value of a product that had only a use value then becomes an exchange value (selling value) where the value of the need for this product is determined through the price that has been designed by the producer (Ibrahim \& Akhmad, 2014).

In this study, researchers used a semiotic analysis to find out what are the symbols, signs, meanings and messages that have religious values from the "Hijab Fresh" Body Lotion product advertisement supported by the brand ambassadore artist who uses the hijab style today, namely Anisha Rahma. There are two series of Hijab Fresh Body Lotion Ads, the "Hijab is Not Your Obstacle" version and "PD Free". But this research will focus on the version of "Hijab is Not Your Obstacle".

The selection of Hijab Fresh Body Lotion adverts as research objects because the ambasadore brand of this product is Anisa ex Cerrybell by using the hijab. The use of the hijab model until the tagline that uses the word "halal" has made several transformations of values into market-oriented exchange rates. Then the researchers formulated the problem "How is the commodification of Islamic religious values in the Hijab Fresh's Body Lotion ads whose the "Hijab is Not Your Obstacle" version?"

\section{Research Method}

This research uses a qualitative approach. Qualitative research is a study that aims to express a picture or understanding of how and why a phenomenon or reality occurs (Pawito, 2008). In addition, qualitative research is aimed at understanding social phenomena from the perspective of the participant (Moleong, 2017).

In this study, researchers used a constructivist paradigm. The constructivist paradigm, that is, a paradigm that is almost an antithesis of understanding that places observations and objectivity in discovering a reality or science. This paradigm views social science as a systematic analysis of socially meaningful action through direct and detailed observation of the relevant social behavior creating and maintaining or managing their social world (Hidayat, 2002). This paradigm is to explain 
the science of idiographic rather than nomothetic because science reveals that reality is displayed in symbols through descriptive forms. The constructivist paradigm is also capable of developing a Penhamana that helps the process of interpreting the process of interpreting an event (Hayuningrat, 2010).

\section{Data source}

The data source is divided into two parts, namely primary data and secondary data. Primary data is data obtained directly by data collection from the field or its source (Sugiyono, 2008). The primary data in this study is the ads of Hijab Fresh body lotion products. Passingly, secondary data from this study are data obtained from relevant literature with the title of the study both from books, articles, websites, news and other sources that support.

\section{Data Collection Technique}

Data collection techniques in this research are through data collection techniques using visual material studies. Sometimes visual material has the same properties as the study of documentation, it's just that the study of documentation does not have the nature of photography. Documentation studies are also more directed at official letters or personal documents, while data collection techniques use visual material as a whole using digital technology (Bungin, 2007). In this study also uses document study as a secondary data collection technique on research objects obtained from written sources such as archives, official documents, and writings on the internet site, which can support research analysis of symbols and messages contained on advertising.

\section{Data analysis technique}

Data analysis as a process that details efforts formally to find themes and formulate working hypotheses (ideas) as suggested by the data and as an effort to provide assistance to the themes and work hypotheses (Kurniawan, 2018).

Analysis of the data used in this research is Charles S. Peirce's semiotic analysis, in which primary data is obtained from pieces of the advertisement series of the Body Lotion Hijab Fresh product which relate 
to the subject matter of the research, will be entered into a table divided into three sections of signs, objects (sign reference) and interpretation. And in relation to the type of sign from Peirce which further explains that the types of signs such as icons, indexes and simols have nuances that can be distinguished (Bungin, 2007).

Through analysis of the triangular relationship of meaning from Peirce. In this study the researcher will first select pieces of the scene which are considered as a form of commodification of religious values and then will look at the scene in three parts of the Peirce meaning triangle. A sign is something in the physical form that can be captured by the five human senses and is something that refers (represents) another thing outside the sign itself. The sign can also refer to the denotatum through convention, which is a symbol that the sign shows the natural relationship between the marker and its signifier (Sobur, 2001). Reference rather than signs are objects, which are social contexts in implementation as aspects of meaning or are referred to by these signs. And interpretation is the concept of thought of someone who uses a sign and passed it on to a particular then or meaning that is in the mind of someone object that is referred to a sign (Kriyantono, 2006)

\section{Results and Discussion}

The issue of the commodification of religious values is often a study in communication science. Among other things, the Commodification of Religious Values in Advertising (Study of Semiotic Analysis of the Commodification of Religious Values on Advertisements of Three Legs Solution). Riana explained the meaning of the signs of the commodification of religious values in the television commercials of the Three Legs Solution in its three versions using the theory of Charles Sanders Pierce's semiotics and the theory of Reality Construction. The results of the study found signs and meanings that identify the commodification of religious values, namely ambasador models or Brand Ambasadore a preacher who is sure to be a role model in Islamic da'wah, place settings in places of study and clothing used are Muslim clothing (Riana, 2014).

Secondly, the commodification of religious values in Semiotic analysis television commercials on Wardah Ads. Based on the results of 
Peirce's analysis of the Wardah television commercial version: Dian Pelangi, in Search of a Beauty, and True Colors, signs and meanings were identified that identified the commodification of religious values in the advertisement. It began with marketing the concept of cosmetics that are safe in terms of religion and beauty from a commercial perspective which is then manifested in an advertisement so that religious values begin to emerge, advertisements containing elegant women in Muslim clothing and halal values are also found in advertisements as guarantee that wardah products are safe products (Wahidah, 2015).

Third, Hijab Commodification in Shampoo Sunsilk Clean And Fresh Ads on Television with the results of the research found signs and meanings that identify the practice of hijab commodification in the ad. Commodification of media content as happened through reconstruction of reality which in this case is the use of hijab. Shampoo Sunsilk Clean and Fresh tries to sell its message to the public through advertisements that air on television using the hijab theme. Among them is the use of hijab which is visualized by all actors in three Sunsilk Clean and Fresh shampoo ads (Indriyani, 2016).

\section{Political Economy and the Commodification of Religion in Mass Media}

This study uses a conceptual framework in Vincent Mosco's political economy economic theory that political economy can be reviewed narrowly and broadly. Political economy can be narrowly interpreted as the study of social relations, especially power relations which together shape the production, distribution, and consumption of resources. The resources in question are including communication products such as newspapers, books, advertisements, videos, films, and audiences. The political economy theory of Mosco's view involves three main activities, namely commodification, spatialization, and structuration (Mosco, 2009)

Commodification in the Mosco communication study explains that commodification is a process that involves changing or transforming media messages into marketed products. There are three forms of commodification in the media context, namely the commodification of content, the commodification of audience, and the commodification of labor. This research focuses on the commodification of media content. 
Commodification of media content involves the process of transforming message content so that the message can be received by the market. The process of commodification of content through the transformation of messages conveyed from data to meaningful systems of thought into marketable products. It can also be said commodification in this form is the process of changing the message of a set of data into a system of meaning in products that can be marketed. In other words the commodification of media content involves the transformation of messages as a result of the professional's ability to produce a story in a system that is filled with meaning which then becomes a product for marketing.

\section{Islamic Religious Values}

Value is a belief based on a code of ethics in society. Value is relative because what one thinks is good, not necessarily good according to others is good. The determination of values must be based on the views and measurements of the people. Etymologically, religion implies mastery, obedience, and retribution (Liliweri, 2015). While religion is defined as a terminology of a set of beliefs, laws, norms or procedures for human life in relation to God and others who will deliver humans to the happiness of life in the world and the hereafter Religion includes three important systems (Noor, 2014), namely: a system of belief in God, a system of worship to God, and a system of values that governs human relations with God (vertical relations) and human relations with humans (horizontal relationships).

Thus, the religious value referred to by the author is the procedure for human life in relation to God and his fellow humans to get the happiness of living in this world and the hereafter. Religious values are individual and are the personal and most profound personal property of a person. The value of religion examined is the value that exists in Islam. This is interesting for the writer, because religion is deliberately commodified with such a concept.

Religious values are also called Rabbani values or divine values that are guilty of God and have a divine nature. Rabbani's values are constantly shown to humanity, transcending space and time. The religion of Islam as a source of value contains provisions regarding aqidah, 
syariah and morality. The forms of Islamic Values are numerous and can be seen from various aspects of life.

In Islam there are two categories of values. First, normative values are values in Islam that are related to good and bad, right and wrong, blessed and condemned by Allah. Second, operative values, namely values in Islam include those that become the principle of standardizing human behavior including: (a) Obligatory, if done to get reward and if left to get $\sin ,(b)$ Sunnah, when it is done gets merit and if it is left innocent, (c) Mubah, if done does not get sin and if not done get a reward, (d) Makruh, if done do not get sin (but hated by God) and if not done do not get both (nutmeg and sin), and (e) Haram, if it is done it gets sin and if it is not done it gets reward.

The five values apply in the usual situations and conditions, except when there is a change in law if an emergency situation. So the five values will change if there is a very urgent illat. The value system can be classified into three groups, namely; (a) The Value of Aqeedah (Faith), the value that relates to how the belief in the heart of his servant towards God as God must be worshiped or in this case is the value of one's religion, (b) Shari-ah Values (A guide in running the life of the world and the Hereafter). According to (Alim, 2006) sharia as rules or points outlined by God so that humans hold on to it, in regulating human relations with God, fellow human beings, nature and human relations with life, (c) Akhal values (decency), values related to ethics or norms. In terms of moral values, morals keep a very important position in Islamic religion. In Surah Al-Qoalam verse 4 explains that the importance of morals. "And in fact you are truly virtuous manners".

Akhlah not only for social but morals are divided into two, morals towards God ranging from faith, ihsan, taqwa, sincere, tawakal, gratitude, and patience. Both morals towards humans, moral values towards humans, among others, silahturami, ukhuwah (brotherhood), positive thingking, Fair, frugal, generous, generous and humble.

\section{Reality Construction}

Advertising has indeed become part of a strong capitalist industrial society and is difficult to avoid. Advertising exists on every medium that is used and develops rapidly with the development of technology and 
information. Advertising provides a picture of reality while defining the will and desires of the individual. And various ways are used so that the message given by the advertiser reaches the public that can give the desired impression and effect by the advertiser (Lukitaningsih, 2013).

Social reality is the result of social construction in certain communication processes. When discussing the theory of social construction, it is inseparable from the theoretical building put forward by Peter L. Berger and Thomas Luckman in his book entitled The Social Construction of Reality: A Treatise in The Sociological of Knowledge in 1966. The term construction of social reality seems famous since introduced by Peter L. Berger and Thomas Luckman. He described the social process through its actions and interactions, where individuals create continuously a reality that is shared and subjectively experienced together subjectively.

Berger and Luckman began to explain social reality by separating understanding between reality and knowledge. Reality is interpreted as a quality contained in realities that are recognized as having an existence that is not dependent on our own will. Whereas knowledge is defined as certainty that realities are real and have specific characteristics.

Dialectics occurs between individuals creating society and society creating individuals. This dialectical process takes place through processes of externalization, objectivity, and internalization. Frans M. Parera explained that the main task of the sociology of knowledge is to explain the dialectics between oneself and the sociocultural world. This dialectic takes place in a process with three simultaneous moments (Bungin, 2007), namely externalization, objectivity, and internalization. Content of social media construction and the birth process of social media construction through the stages of preparing construction material, the stage of construction distribution, the stage of construction of reality construction and the confirmation stage. Through media construction, it can be explained how the mass media make a picture of reality.

\section{Charles Sanders Peirce's Semiotic Analysis}

Etymologically, the term semiotics comes from Greek, which means "Sign". The sign itself is defined as something which, on the basis of previously established social conventions, can be considered to represent 
something else. Semiotics is the science of signs. The study of signs and everything related to them, how they function, their relationship with other signs, their delivery and their acceptance by those who use them. Preminger considers that social or community phenomena and culture are signs (Sobur, 2001). Semiotics studies the systems, rules, conventions that enable these means to have meaning. Important figures in importance in the field of semiotics are Charles Sanders Peirce (18341914) and Ferdinand de Saussure (1857-1913).

In this study, researchers used a semiotic analysis of Charles Sanders Peirce. Charles Sanders Peirce is the most original and multidimensional argumentative thinker and American philosopher (1839-1914). According to Peirce, signs, objects, and interpretants are three elements of meaning that interact in a person's mind, so that meaning will appear about something that is represented by the sign (Sobur, 2003)

According to Peirce, "something which stands to somebody for something in some respect or capacity" (a sign is everything that exists in someone to express something else in some way or capacity). Something that is used so that the sign can function, by Peirce is called ground. Consequently, the sign (sign or representamen) is always contained in a triadic relationship, namely ground, object, and interpretant or commonly called a triangle meaning or triangle meaning (Eco, 1979).

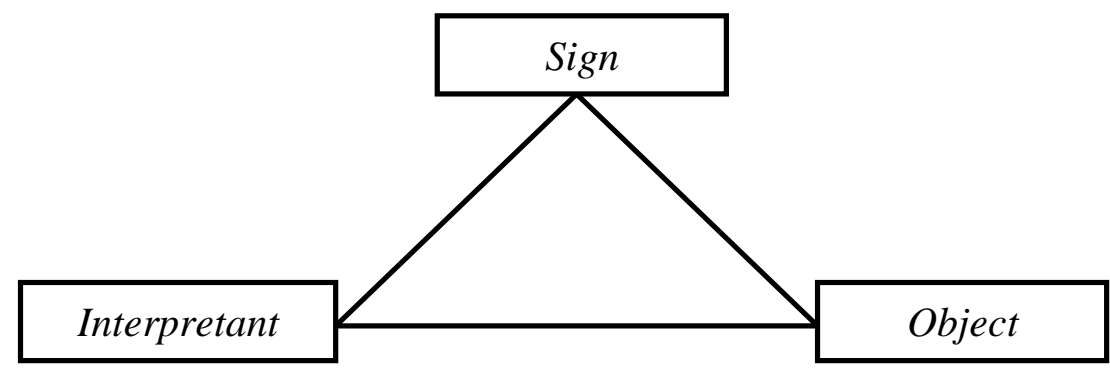

Picture 1: Peirce's Meaningful Triangle Schema

a. Sign is something in the physical form that can be captured by the five human senses and is something that refers (represents) something other than the sign itself. This reference sign is called an object. 
b. Object reference is a social context that is a reference to a sign or something that a sign refers to.

c. User Sign or Interpretant is the concept of thought of people who use the sign and reduce it to a certain meaning or meaning that is in someone's mind about the object to which a sign is referenced.

d. Symbol. A sign in which the relationship between the sign and its reference is a relationship that has been formed conventionally. This symbol is a sign formed because of the consensus of the sign users.

e. Icon. A sign where the relationship between the sign and its reference is in the form of a similarity relationship. Thus, the icon is a sign that in various forms resembles the object of the mark.

f. Index. A sign in which the relationship between the sign and its reference arises because of the closeness of the extension. So the index is a sign that has a direct relationship (causality) with the object.

According to Peirce, an analysis of the essence of signs leads to proof that each sign is determined by its object. First, by following the nature of the object, when we call the sign of an icon. Second, it becomes reality and its existence is related to individual objects, when we mention the sign of an index, the third is more or less, a definite estimate that it is interpreted as a denotative object as a result of a habit when we call the sign of a symbol. Basically, something is said to be a valid sign when it has a reasonable form (can be repeated and can be predicted) and arranged in a way that can be defined (patterned). Three types of signs namely icons, indexes, and symbols developed by Charles Peirce are very useful in various cultural phenomena, such as media products (Danesi, 2010).

This study uses a semiotic analysis developed by Charles Sander Peirce. By using this semiotic analysis, the author examines the research by examining the markings in the Hijab Fresh product advertisement. The reason the author uses Peirce's semiotics analysis is very useful in cultural phenomena such as media products, because in a book entitled Communication Semiotics it is stated that if you want to explore the meaning behind an advertisement, you should use the Peirce semiotic model (Wibowo, 2013). Another reason Pierce's semiotic model is also 
more flexible is used to examine visuals both advertisements and films, unlike others that are more based on linguistics. In addition, Pierce's semiotics is pragmatic, namely semiotics that studies the relationship between signs and their interpreters or users (Budiman, 2011).

Another reason Pierce's semiotic model is also more flexible is used to examine visuals both advertisements and films, unlike others that are more based on linguistics. In addition, Pierce's semiotics is pragmatic, namely semiotics that studies the relationship between signs and their interpreters or users (Vera, 2014).

\section{Hijab Fresh Body Lotion Profile}

Fresh Hijab Body Lotion product is an output from PT. Unilever Indonesia which was launched in 2017 in Jakarta. The launch of this product is specifically for women who wear hijab, according to data from the Pew Research Center on Religion and Public Life, the number of Indonesian women wearing hijab has reached 20 million people and continues to increase by $73 \%$ in the next 4 decades. Hijab Fresh's products make Anisa Rahma Adi, a former Indonesian girl band member CherryBell, is a brand ambassador.

The product launched by PT Unilever Indonesia Body Lotion Hijab Fresh 4 different variants that are tailored to the skin type of Indonesian women. First, the Health and Brith matcha leaf for normal skin and keep the skin fresh cool all day. Second, Extra Moisture with cucumber for dry skin that will keep skin soft and moisturized. Third, Nourish and Protech pomegranate is suitable for use in active outdoor activities with SPF 24 UV Protection. Fourth, Cool and Fresh with mint extract gel for normal skin.

Hijab Fresh Body Lotion products have the first 2 forms of sachets which can be priced at IDR 2,000 and bottles of $100 \mathrm{ml}$ and $200 \mathrm{ml}$ at IDR 5,000 and IDR 10,000-15,000.

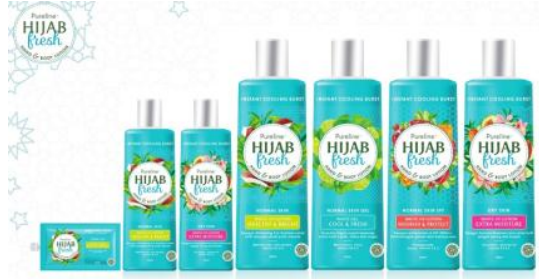

Picture 2. Fresh Hijab Body Lotion Products 


\section{The Ads of Hijab Fresh Body Lotion}

The HijaB Fresh Body Lotion ad that was studied was the series version that the researcher took from the uploaded YouTube website ALC TV Indonesia Official and Iklanesia HD with the time difference when uploaded.

The first version that is "Hijab Bukan Halanganmu" was uploaded on June 1, 2019 with a duration of 15 seconds and the second version "Bebas PeDe" was uploaded on September 15, 2017 with a duration of 31 seconds. This 15 -second ad will feature Dianandra Choirunnisa as the National Archery Alet and the 2017 SEA Games gold medalist preparing for archery. The initial setting is done in the open field during the day to do archery training and after that proceed with the background room and use body lotion.

\section{Identification and Classification of Signs}

Table 1. Identify The Signs On The Ads Series Of Fresh Hijab Body Lotion Products "Hijab Bukan Halanganmu"

\begin{tabular}{lll}
\hline No & Frame & $\begin{array}{c}\text { Type } \\
\text { Analysis }\end{array}$ \\
\hline 1. & $\begin{array}{l}\text { Icon } \\
\text { The visual model is an } \\
\text { archery scene by } \\
\text { Dianandra } \\
\text { Choirunnisa who feels } \\
\text { her skin is blackened }\end{array}$ \\
\hline 2. & Icon & $\begin{array}{l}\text { The visual is product } \\
\text { packaging }\end{array}$ \\
\end{tabular}




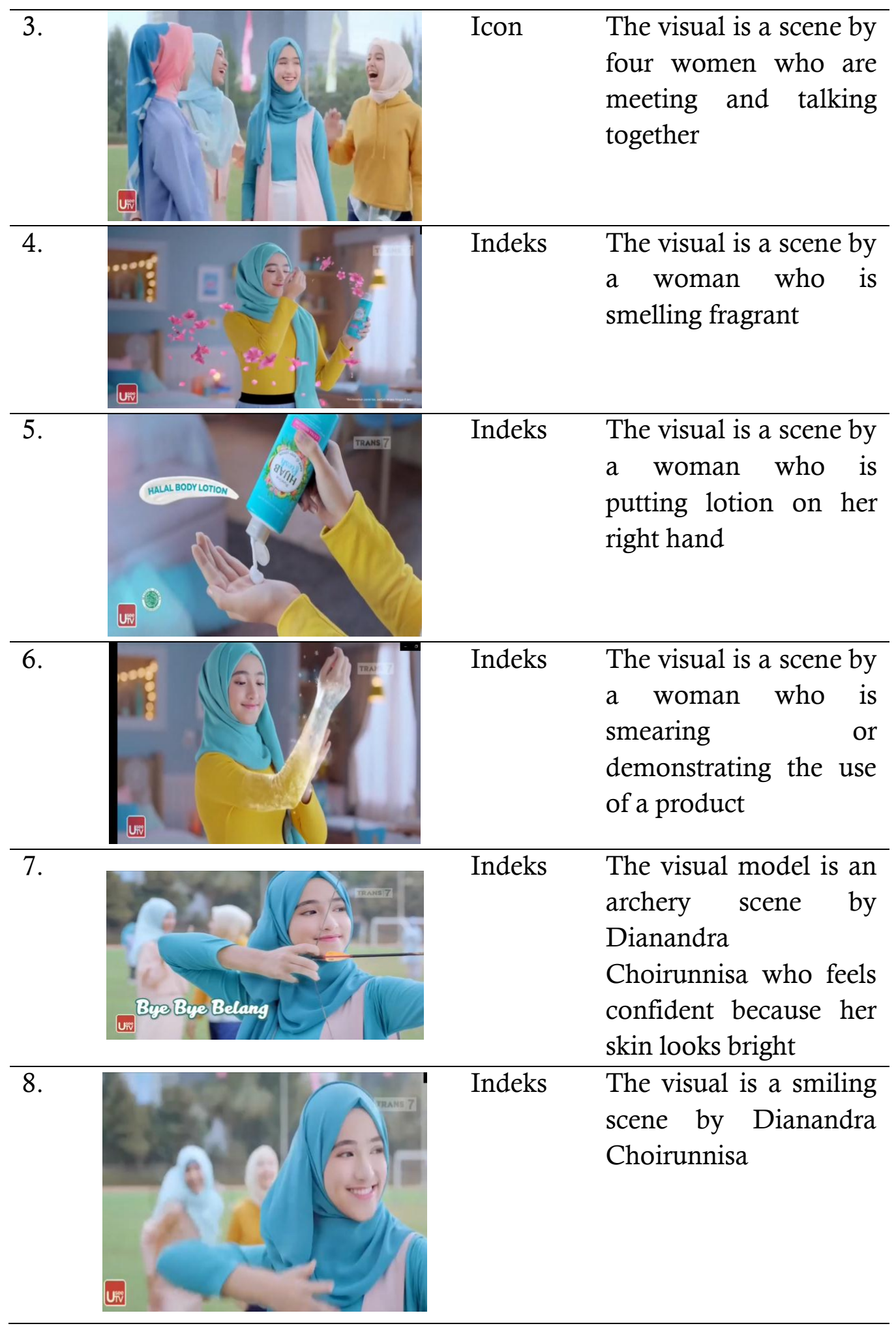




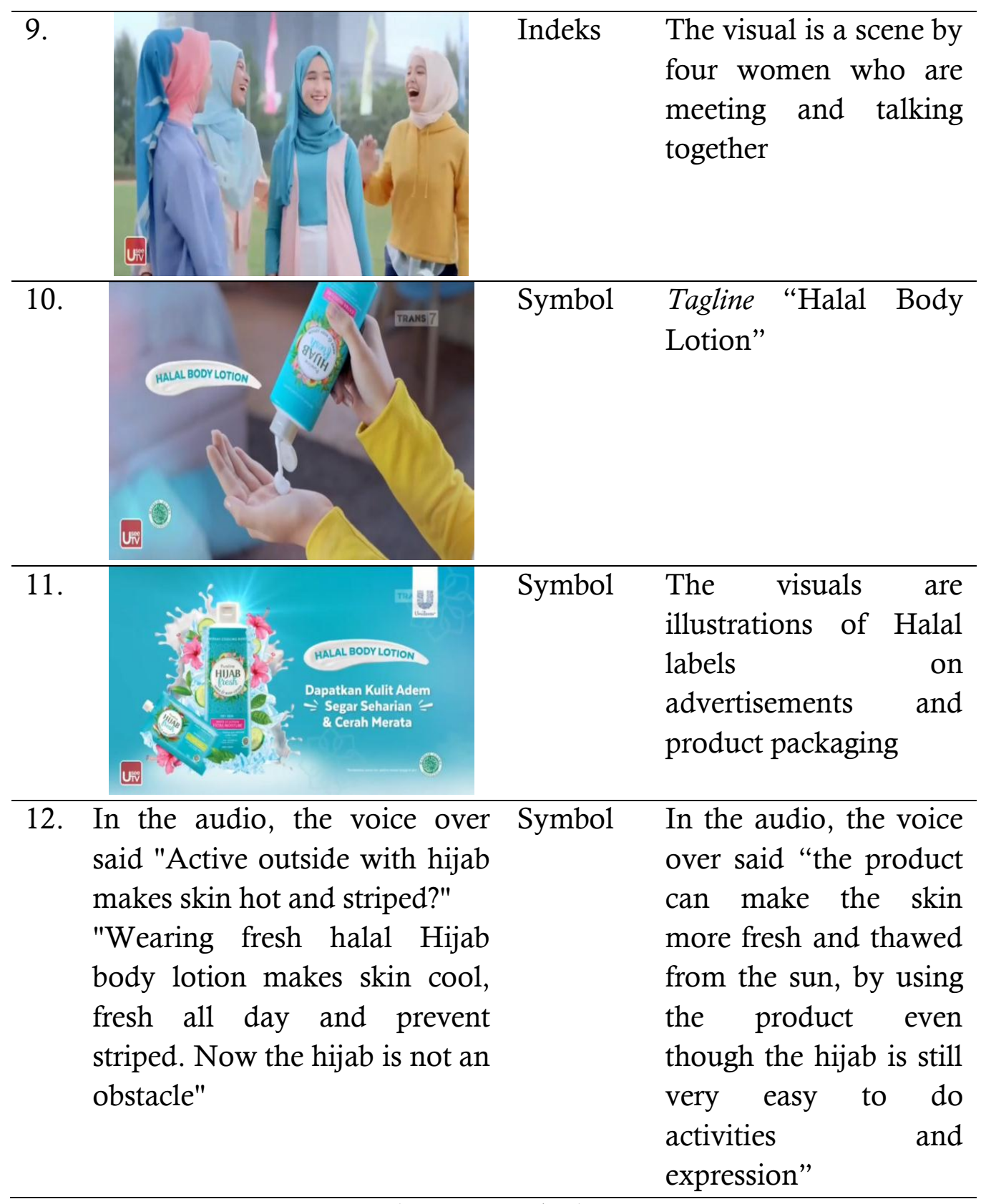

(Source: Author)

Meaning Interpretation based on Identification of Types of Signs in Ads

Based on the Identification of the sign in the advertisement for a fresh halal hijab body lotion product version "Hijab is Not Your Obstacle" which is done with this type of mark by Charkes S. Peirce. 
After the identification process, the researcher will interpret the meaning contained through the triangles of meaning, namely signs, objects and interpretants.

\section{Interpretation of meaning based on the Identification of the Type of Icon Sign}

Table 2. Interpretation Of Meanings Based On Identification Of Types Of Icon Signs

\begin{tabular}{|c|c|c|c|}
\hline No & Signs & Object & Interpretation \\
\hline 1. & Visually, Dianandra & Just like a sign & Describes that Dianandra \\
\hline & $\begin{array}{l}\text { Choirunnisa is an } \\
\text { Archery athlete }\end{array}$ & & $\begin{array}{l}\text { Choirunnisa can easily } \\
\text { move without fear of } \\
\text { being separated from the } \\
\text { role of Hijab Fresh's body } \\
\text { lotion. }\end{array}$ \\
\hline 2. & $\begin{array}{l}\text { Visual of the } \\
\text { packaging }\end{array}$ & Just like a sign & $\begin{array}{l}\text { Introducing halal body } \\
\text { lotion products and } \\
\text { suitable for Muslim } \\
\text { women. }\end{array}$ \\
\hline 3. & $\begin{array}{l}\text { Visuals of the four } \\
\text { women talking } \\
\text { together }\end{array}$ & Just like a sign & Describing friendship. \\
\hline
\end{tabular}

(Source: Author)

Based on the results of the identification conducted by researchers on the adverts of the fresh hijab body lotion product version "Hijab Not Your Obstacle" there are three types of iconic markings. First is visul from Dianandra Choirunnisa as a national archery athlete who is preparing for archery training. As a national athlete training without obstacles greatly affects the performance of a person in his training, although wearing a hijab may not necessarily be able to perform activities or activities comfortably. Dianandra is also a SEA Games 2017 gold medalist. By using body lotion from Hijab fresh even though outdoor training which is indeed archery training outside the field will not be striped and even though sweating the skin will remain fresh. Which means that Diandra as an advertising model indirectly that by using fresh 
Hijab products will be more fresh and comfortable without fear of sunlight. This can be seen from the relationship of icons, indexes and symbols that Dianandra used Hijab Fresh products before her activities.

The last icon of the visuals of the four women being together, shows that friendship and friendship are supportive for sharing success and social sharing. In the value of Islamic religion, friendship is important in the value of sharia and morals as religious people to give and complement each other.

\section{Meaning Interpretation Based on Identification of Types of Index Signs}

Table 3. Meaning Interpretation Based On Identification Of Types Of Index Signs

\begin{tabular}{|c|c|c|c|}
\hline No & Sign & Object & Interpretation \\
\hline 1. & $\begin{array}{l}\text { Clothes and } \\
\text { colors }\end{array}$ & $\begin{array}{l}\text { Muslim clothing } \\
\text { shows that the } \\
\text { model is a } \\
\text { follower of Islam. }\end{array}$ & $\begin{array}{l}\text { Showing that the product is } \\
\text { safe, clean and lawful to be } \\
\text { used especially for Muslim } \\
\text { women. }\end{array}$ \\
\hline 2. & $\begin{array}{l}\text { Put lotion in } \\
\text { her hands }\end{array}$ & Positive thing & $\begin{array}{l}\text { Showing how the product } \\
\text { should be used with good } \\
\text { and positive hands. }\end{array}$ \\
\hline 3. & $\begin{array}{l}\text { Demonstrate } \\
\text { using the } \\
\text { product }\end{array}$ & Positive thing & $\begin{array}{l}\text { This shows that using the } \\
\text { product and giving the } \\
\text { impression that the Hijab } \\
\text { Fresh body lotion product } \\
\text { gives a positive thing. }\end{array}$ \\
\hline 4. & Doing archery & Positive thing & $\begin{array}{l}\text { This shows that the hijab } \\
\text { does not preclude activities, } \\
\text { one of which is the activity } \\
\text { of sports. }\end{array}$ \\
\hline 5. & Smile & $\begin{array}{l}\text { Greetings } \\
\text { happiness }\end{array}$ & $\begin{array}{l}\text { Shows that using Fresh Hijab } \\
\text { products is very comfortable } \\
\text { without obstacles. }\end{array}$ \\
\hline
\end{tabular}




$\begin{array}{ll}\text { 6. Gather and Positive thing } & \text { Show that success will be } \\ \text { joke together } & \text { happier when together and } \\ & \text { with the support and } \\ & \text { motivation of those closest to } \\ & \text { you. }\end{array}$

(Source: Author)

Based on the results of identification carried out on the fresh Hijab body lotion ad series, six index types were obtained. First, clothing and color. The clothing worn by the advertising model in this advertisement shows that the identity of the advertising models is the followers of Islam, using covered and long clothes and wearing hijab. The colors used are also soft, bluish green, beige which shows a soft, loyal, cheerful and trustful atmosphere (Darmaprawira, 2008)

The second type of index mark is to use lotions with the right hand. Wearing the product with the right hand is indicative of an object that gives a positive impression which in Islam carries out all activities with the right hand and shows the value of politeness. Third, demonstrate using the product. The second and third indices are interrelated, using the product with the right hand to polish on the skin and show the procedures for using it. The fourth index index is doing archery. Sport is a positive activity, in addition to being healthy it can also produce pride if you enter a race. Even though sports that are challenging and are impressed by men's sports from archery, especially women who wear hijab, can also be active and achieving.

The fifth index sign is a smile. Smiles in Islam are positive values signifying greetings, which Islam teaches to always be happy "Smiles are worship" worship in the form of alms to make people happy. Friendly greetings and radiating happiness are smiles (HR Imam Turmudzi, Ibn Hibban dan Al Baihaqi).

Finally, the sixth index mark gathered and joked with laughter together. Social is important in the lives of fellow human beings, friends and friends are strongly encouraged to complement each other and provide motivation. Friendship in Islam is a moral value to respect fellow human beings without valuing differences (Azizah \& Kurniawati, 2013). 
Meaning Interpretation Based on Identification of Types of Symbols

Table 4. Meaning Interpretation Based On Identification Of Types Of Symbols

\begin{tabular}{|c|c|c|c|}
\hline No & Signs & Object & Interpretation \\
\hline 1. & $\begin{array}{l}\text { Halal labels } \\
\text { appear on ads } \\
\text { and product } \\
\text { packaging. }\end{array}$ & $\begin{array}{l}\text { The label in } \\
\text { the ad is under } \\
\text { the right and } \\
\text { on the product } \\
\text { packaging. }\end{array}$ & $\begin{array}{l}\text { Showing with the halal label } \\
\text { makes the product more } \\
\text { trusted and safe to use, } \\
\text { especially to attract the } \\
\text { Muslim community. }\end{array}$ \\
\hline 2. & $\begin{array}{l}\text { The audio, } \\
\text { voiceover said } \\
\text { "Being active } \\
\text { outside with hijab } \\
\text { makes skin hot } \\
\text { and striped? , } \\
\text { Wearing fresh } \\
\text { Hijab halal body } \\
\text { lotion makes skin } \\
\text { cool, fresh all day } \\
\text { and prevent } \\
\text { stripes. Now the } \\
\text { hijab is not an } \\
\text { obstacle" }\end{array}$ & $\begin{array}{l}\text { Audio from } \\
\text { voiceover }\end{array}$ & $\begin{array}{l}\text { Showing that body lotion } \\
\text { products from Hijab Fresh by } \\
\text { using it will not make hot } \\
\text { and striped skin for Muslim } \\
\text { women who wear jihab } \\
\text { which is certainly safe } \\
\text { because of halal, without fear } \\
\text { of disrupted activity. }\end{array}$ \\
\hline
\end{tabular}

(Source: Author)

Based on the results of the identification of the Hijab Fresh body lotion advertisement "Hijab is not your obstacle", there are two types of symbolic signs. The first type of symbol is the halal label in advertisements and packaging. Halal is something that is permitted by God in His book. In Indonesia, there is a body that deals with halalharam, something that is the MUI (Indonesian Ulema Council) where each product must contain halal labels because the majority of Indonesian people are Islamic. And the Hijab Fresh body lotion product has received a halal certificate after the MUI Fatwa was issued in 2011 concerning the determination of halal products. And the interpretation 
that emerges that halal products can be an attraction especially Muslim women.

Next, the second audio audio symbol. Audio is one of the main sign elements in an ad. Audio is generally sometimes used to show messages directly and clearly. From the audio presented, the advertisement can be interpreted with affirmations that lead to the product. In the first audio "Active outside with hijab makes hot and striped skin". Second, "Wearing fresh halal Hijab body lotion makes skin cool, fresh all day and prevent stripes" and the third "Now Hijab is not an obstacle". Voiced explains several verbal meanings. That being active outside by using the hijab will make the skin hot and striped, because using the hijab will cover many parts of the body and it is easy to feel hot and some parts of the body that open will become black and make the skin uneven white. Then by using halal body lotion products from Hijab, fresh eating will be more comfortable, fresher and not afraid of streaking. And activities outside the room will be comfortable without fear of anxiety. And even though using the hijab will not inhibit activity and can continue to move.

So the social construction to be conveyed is the importance of this product for young teenagers who wear hijab so they can continue to have activities and achievements. The basic principle of the distribution of social media construction is that all information must arrive at the right audience based on the agenda of the media. By emphasizing products for Muslim and halal people, it is hoped that social construction will be built in the consumer society to consume this body lotion.

\section{Conclusions}

Based on the findings and discussions that have been presented, in the Hijab Fresh Body Lotion Product Advertisements, the value of Commodification occurs with the practice of religious values through visual signs, indices and symbols in the advertisement. In this study sacred religions are based on beliefs about God transformed into an exchange value. This process of commodification occurs through a shift in the message and the impression given is seen from the clothing used by actors in advertisements (clothing that is closed according to Islamic sharia), the behavior of actors in accordance with Islamic teachings and messages with words that reinforce advertising in the form of audio or 
written on packaging and advertising in mass media. From these messages and impressions produced values of Islam that have been commodified. Although the value of Islamic religion has shifted but the function of religious teachings remains in line which means it remains true according to Islamic religion, ranging from Muslim clothing and halal products which are guarantees in these products to be safe for consumption by Muslim women.

\section{Bibliography}

Alim, M. (2006). Pendidikan agama Islam: upaya pembentukan pemikiran dan kepribadian muslim (D. Wijaksana (ed.); 1st ed., Vol. 1). Bandung: Remaja Rosdakarya.

Azizah, N., \& Kurniawati, Y. (2013). Tingkat Keterampilan Berbicara Ditinjau Dari Metode Bermain Peran Pada Anak Usia 5-6 Tahun. Indonesian Journal of Early Childhood Education Studies, 2 (2), 50-57. https://doi.org/10.15294/ijeces.v2i2.9241

Budiman, K. (2011). Semiotika Visual: Konsep, Isu, dan Problem Ikonisitas (1st ed., Vol. 1). Yogyakarta: Jalasutra.

Bungin, B. (2007). Penelitian kualitatif: Komunikasi, ekonomi, kebijakan publik, dan ilmu sosial lainnya (D. A. Riyadi (ed.); 2nd ed., Vol. 8). Yogyakarta: Kencana.

Danesi, M. (2010). Pengantar Memahami Semiotika Media (1st ed., Vol. 1). Yogyakarta: Jalasutra.

Darmaprawira, S. W. (2008, April 22). Warna: teori dan kreativitas penggunaannya. Koleksi Buku UPT Perpustakaan Universitas Negeri Malang.

http://library.um.ac.id/freecontents/download/pub/downloadprint2.php/15208.pdf

Eco, U. (1979). A Theory of Semiotics (1st ed., Vol. 1). Indiana Univesity Press.

Fakhruroji, M. (2014). Komodifikasi Agama Sebagai Masalah Dakwah. Jurnal Ilmu Dakwah, 1 5(16), https://doi.org/10.15575/jid.v5i16.352

Fealy, G., \& White, S. (2008). Expressing Islam: Religious Life and Politics in Indonesia (A. Grant (ed.); 1st ed., Vol. 1). Singapore: Seng Lee Press Pte LTd. 
Habermas, J. (2015, August 17). Habermas receives Kluge Prize. Goethe University Frankfurt.

https://www.eurekalert.org/pub_releases/2015-08/gufhrk081715.php

Hayuningrat, P. S. (2010). Media Literacy Khalayak Dewasa Dini Pada Tayangan Reality Show Di Televisi (Studi Kasus Pada Khalayak Reality Show Orang Ketiga). http://lib.ui.ac.id/file?file=digital/132913-SK 0012010 Hay m - Media literacy - Abstrak.pdf

Hidayat, D. N. (2002). Metodologi Penelitian dalam Sebuah "MultiParadigm Science." Mediator: Jurnal Komunikasi, 3(2), 197-220. https://doi.org/10.29313/MEDIATOR.V3I2.766

Ibrahim, I. S., \& Akhmad, B. A. (2014). Komunikasi dan Komodifikasi:

Mengkaji Media dan Budaya dalam Dinamika. In A. H (Ed.), in Pustaka Obor (1st ed., Vol. 1). Yogyakarta:Pustaka Obor.

Indriyani, P. I. (2016). Komodifikasi Hijab Dalam Iklan Sampo Sunsilk Clean And Fresh Di Televisi SKRIPSI Diajukan kepada Fakultas Dakwah dan Komunikasi Universitas Islam Negeri Sunan Kalijaga Yogyakarta Untuk Memenuhi Sebagian Syarat-syarat Memperoleh Gelar Sarjana Strata 1 Disu [UIN $\quad$ SUKA]. http://digilib.uinsuka.ac.id/21214/2/12210049_BAB-I_IV-atau-V_DAFTARPUSTAKA.pdf

Kamim, A. B. M. (2017, November 20). Bertahan di Tengah Guncangan Komodifikasi Agama.

https://jmf.fisipol.ugm.ac.id/2017/11/bertahan-di-tengahguncangan-komodifikasi-agama/

Kriyantono, R. (2006). Teknik Praktis Riset komunikasi (1st ed., Vol. 1). Yogyakarta: Kencana.

Kurniawan, D. (2018). Komunikasi Model Laswell Dan StimulusOrganism-Response Dalam Mewujudkan Pembelajaran Menyenangkan. Jurnal Komunikasi Pendidikan, 2(1), 68. https://doi.org/10.32585/jkp.v2i1.65

Liliweri, A. (2015). Komunikasi Antar Personal (1st ed., Vol. 1). Jakarta: Prenadamedia Group.

Lukitaningsih, A. (2013). Iklan Yang Efektif Sebagai Strategi Komunikasi Pemasaran. Jurnal Ekonomi Dan Kewirausahaan, 13(2), 116-129. 
Moleong, L. J. (2017). Metodologi Penelitian Kualitatif (Edisi Revisi). In Remaja Rosda Karya (37th ed., Vol. 1). Bandung: Remaja Rosdakarya. https://doi.org/10.1016/j.carbpol.2013.02.055

Mosco, V. (2009). The Political Economy of Communication (1st ed.). New York: SAGE Publications Ltd.

Murtadho, A. (2016). Economica: jurnal pemikiran dan penelitian ekonomi Islam. Economica: Jurnal Ekonomi Islam, 7(2), 1-26. https://doi.org/http://dx.doi.org/10.21580/economica.2016.7.2.11 53

Noor, W. (2014). Rekonstruksi Pendidikan Agama Islam. Jurnal Qathrunâ, $1(1)$ 40-59. https://core.ac.uk/download/pdf/267961699.pdf

Pawito. (2008). Penelitian Komunikasi Kualitatif. In Buku (1st ed., Vol. 1, Issue 2). Yogyakarta: LKiS.

Piliang, Y. A. (2012). Semiotika dan hipersemiotika: kode, gaya \& matinya makna (4th ed., Vol. 1). Jakarta: Matahari.

Riana, G. V. (2014). Komodifikasi Nilai Agama Dalam Iklan Televisi (Studi Analisis Semiotik Komodifikasi Nilai Agama Terhadap Iklan Larutan Cap Kaki Tiga). http://digilib.uin-suka.ac.id/13789/1/BAB I, IV, DAFTAR PUSTAKA.pdf

Sobur, A. (2001). Analisis Teks Media: Suatu Pengantar untuk Analisis Wacana, Analisis Semiotik, dan Analisis Framing (1st ed., Vol. 1). Bandung: Remaja Rosdakarya.

Sobur, A. (2003). Semiotika Komunikasi (1st ed., Vol. 1). Bandung: Remaja Rosdakarya.

Sugiyono. (2008). Metode penelitian pendidikan: (pendekatan kuantitatif, kualitatif dan $R \& D)$ ). Bandung: Alfabeta.

Vera, N. (2014). Semiotika dalam Riset Komunikasi (R. Sikumbang (ed.); 1st ed., Vol. 1). Semarang: Ghalia.

Wahidah, F. (2015). Komodifikasi Nilai Agama Dalam Iklan Televisi (Studi Analisis Semiotik pada Iklan Wardah). http://eprints.walisongo.ac.id/4778/1/101211051.pdf

Wibowo, I. seto W. (2013). Semiotika Komunikasi:Aplikasi Pratik bagi penelitian dan Skripsi Komunikasi (1st ed.). Mitra Wacana Media. 